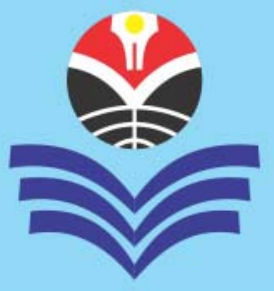

\title{
Analisis Isi Pesan Nilai dalam Suratkabar Singgalang untuk Pengembangan Materi pada Mata Pelajaran Pendidikan Kewarganegaraan
}

\begin{abstract}
ABSTRAKSI: Media massa merupakan sarana dalam mencari informasi yang cukup dipercaya oleh masyarakat. Penelitian ini justru dilatarbelakangi oleh banyaknya guru PPKn (Pendidikan Pancasila dan Kewarganegaraan) saat ini yang menugaskan siswa untuk menggunakan media massa sebagai sumber belajar. Hal ini sebagai konsekuensi pelaksanaan Kurikulum 2013, yang menghendaki siswa mengumpulkan informasi di luar buku teks. Namun, ada yang terlewatkan dari perhatian guru, yaitu bagaimana menggali nilai dari teks yang dibaca. Penelitian ini bertujuan, pertama, untuk membantu proses pembelajaran dengan menelaah isi berita utama suratkabar, yang memuat pesan-pesan nilai spiritual dan sosial; serta, kedua, dapat menjadi model bagi guru dalam menggunakan media massa sebagi sumber belajar. Metode yang digunakan adalah analisis isi. Hasil penelitian menunjukan bahwa dari segi analisis teks, nilai spiritual yang paling banyak ditemukan adalah "tanggungjawab" dan dibawah itu adalah "nilai keadilan"; serta nilai sosial yang terbanyak adalah "nilai tanggungjawab sosial", dengan nilai dibawah itu adalah "kepedulian". Oleh karena itu, pengggunaan media massa sebagai sumber belajar dalam pembelajaran PPKn perlu memperhatikan beberapa pertimbangan, seperti kualitas media, serta keterampilan dalam membaca secara kritis.
\end{abstract}

KATA KUNCI: Nilai spiritual, sikap sosial, guru-siswa, media massa, dan informasi berharga.

ABSTRACT: "Content Analysis on Value Message in Singgalang Newspaper for Materials Development in the Subject of Civic Education". The mass media is a means for searching information that is credible enough for the community. This study was actually motivated by a number of teachers of PPKn (Pancasila and Citizenship Education) who are currently assigning students to use the mass media as a source of learning. This use of media is a consequence of the implementation of Curriculum 2013, which requires students to collect information from outside the textbook. However, something has been overlooked by the teachers, namely how to explore the values from the text to be read. This study aims, firstly, to help the learning process by examining the contents of newspaper headlines, which contain messages of spiritual and social values; and, secondly, produce a model for teachers in using the mass media as a source of learning. The method used is content analysis. The results showed that in terms of textual analysis, the spiritual values most commonly found are "responsibility", followed by "justice"; and the highest social value is "social responsibility", followed by value of "caring". Accordingly, the use of mass media as learning resources in teaching PPKn subject needs to take some measures, such as the quality of mass media as well as skills in reading critically.

KEY WORD: Spiritual value, social attitudes, teachers-students, mass media, and valuable information.

About the Authors: Dr. Isnarmi Moeis dan Dr. Junaidi Indrawadi adalah Staf Pengajar di Program Studi PPKn (Pendidikan Pancasila dan Kewarganegaraan), Fakultas Ilmu Sosial UNP (Universitas Negeri Padang) di Kota Padang, Sumatera Barat, Indonesia. Alamat emel penulis: aanisnarmi213@gmail.com

How to cite this article? Moeis, Isnarmi \& Junaidi Indrawadi. (2016). "Analisis Isi Pesan Nilai dalam Suratkabar Singgalang untuk Pengembangan Materi pada Mata Pelajaran Pendidikan Kewarganegaraan” in MIMBAR PENDIDIKAN: Jurnal Indonesia untuk Kajian Pendidikan, Vol.1(1) Maret, pp.13-24. Bandung, Indonesia: UPI Press.

Chronicle of the article: Accepted (February 13, 2016); Revised (February 23, 2016); and Published (March 11, 2016). 


\section{PENDAHULUAN}

Media massa merupakan sarana mencari informasi yang cukup dipercaya bagi masyarakat. Hasil satu survey di Amerika Serikat, yang dikutip oleh seorang penulis, Wahyu Desy N. (2011), di www.tribuntimur.com, pada tanggal 23 september 2011, menyatakan bahwa 72\% masyarakat menyatakan percaya dengan berita di media massa (Desy N., 2011). Orang yang mengikuti perkembangan berita setiap hari menyatakan lebih percaya kepada media massa daripada pemerintah. Di Indonesia, sebagaimana dikutip lebih jauh, menunjukan bahwa masyarakat lebh percaya kepada media massa daripada pemerintah. Penelitian lain oleh Guafon Wan \& Diane Gut (2008) juga menemukan bahwa remaja di Cina dan di Amerika Serikat menggunakan waktu yang banyak dalam penggunaan media. Media memainkan peran penting dalam kehidupan remaja di Cina dan Amerika Serikat (Wan \& Gut, 2008).

Fenomena ini juga terjadi di sekolah kita hari ini. Kebanyakan guru PPKn (Pendidikan Pancasila dan Kewarganegaraan), terutama yang berada di daerah perkotaan, tidak asing lagi memberikan tugas kepada siswa untuk mencari sumber bacaan di luar buku teks. Ini disebabkan oleh tuntutan Kurikulum 2013, yang mengharuskan siswa menggali informasi sebagai salah satu langkah dari pembelajaran dengan pendekatan saintifik. Implikasinya, guru mengarahkan siswa untuk mencari sumber belajar melalui internet dan koran.

Penekananan pada aspek sikap dalam Kurikulum 2013 menjadi bagian penting, terutama untuk mata pelajaran PPKn, karena prinsip dasar dalam mata pelajaran ini adalah pembentukan karakter warga negara yang baik. Diantara sumber yang digunakan selain buku teks yang diwajibkan, juga siswa diarahkan untuk mengumpulkan bahanbahan bacaan dari internet dan suratkabar. Penggunaan sumber dari media itu lebih banyak dipakai guru sebagai tambahan informasi bagi pembahasan topik tertentu dalam pembelajaran.
Di sisi lain, pesan dalam media massa perlu juga dikaji secara kritis karena banyaknya kepentingan yang masuk dalam sebuah pemberitaan atau tulisan dalam media massa, seperti pertimbangan redaksional, interestinterest politik penulis atau nara sumber berita (Suwirta, 2015). Sebagai contoh, peringatan 20 Mei 2015, yang dipakai mahasiswa sebagai sarana menyampaikan aspirasi terhadap pemerintah, tidak satu pun media massa resmi yang melaporkan peristiwa itu secara utuh. Hal ini bisa dipahami, karena media massa tidak mungkin memberitakan semua realita sebagaimana adanya dengan pertimbanganpertimbangan redaksional.

Tetapi media massa, baik cetak atau elektronik, tetap dibutuhkan bagi pembelajaran. Dalam konteks ini perlu keterampilan dan kemampuan membaca secara kritis yang diajarkan oleh guru kepada siswa agar dapat menyaring informasi secara bermakna. Penelitian ini berupaya menjembatani antara kebutuhan pembelajaran terhadap media massa sebagai sumber belajar di satu sisi, dan kemampuan guru dan siswa yang belum memadai untuk menganalisis isi media massa secara kritis di sisi lain.

Penelitian ini juga merupakan contoh yang dapat digunakan oleh guru jika mereka akan menugaskan siswa untuk mengumpulkan informasi melalui koran sebagai sumber belajar. Untuk penelitian ini dipilih sebagai sampel adalah suratkabar Singgalang, karena merupakan koran lokal di Padang, Sumatera Barat, Indonesia, yang paling banyak diakses di sekolah.

Tujuan penelitian ini adalah untuk menjawab pertanyaan penelitian yang dirumuskan seperti berikut: (1) bagaimana nilai-nilai spritual dan sosial direprentasikan melalui teks berita utama koran Singgalang; (2) bagaimana nilai-nilai spiritual dan sosial diinterpretasikan dari konteks berita atau tajuk suratkabar Singgalang; dan (3) bagaimana implikasi dalam penggunaan suratkabar Singgalang bagi pembelajaran PPKn di sekolah. 
Untuk mendapat data, penelitian ini menggunakan pendekatan analisis isi (Krippendorf, 1980; dan Prasad, 2008). Objek penelitian adalah suratkabar, dalam hal ini suratkabar Singgalang, dengan unit analisis adalah teks berita utama. Kategori analisis isi yang dikembangkan dalam penelitian ini adalah ide utama dan konsep dalam paragraf. Dengan menelusuri kata kunci dalam kalimat utama dan kalimat pendukung, ianya dalam rangka untuk menemukan konsep. Dari konsep ini kemudian disimpulkan apakah ianya mengandung nilai atau tidak; kalau ya, apakah nilai spiritual (religious) atau nilai sosial. Secara diagram, proses tersebut digambarkan dalam bagan 1 .

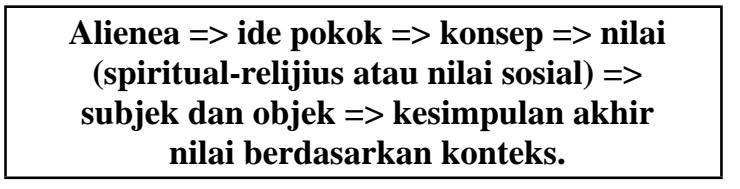

Bagan 1:

Alur Proses dari Berita Menjadi Konsep dan Nilai

Proses mengidentifikasi nilai dilakukan dua kali: pertama, langsung dari konsep tanpa memperhatikan konteks. Kedua, nilai tersebut dikaitan dengan konteks untuk menyimpulkan apakah sifat dari nilai tersebut.

\section{TINJAUAN PUSTAKA}

Media massa merupakan bagian penting dari kehidupan manusia di abad modern, karena perannya yang besar sebagai sumber informasi. Setiap hari, orang merasa perlu tahu berbagai peristiwa di sekitarnya atau di tempat lain dengan berbagai alasan, seperti untuk bisnis, perjalanan, dan sebagainya. Untuk menjawab kebutuhan ini, media massa merupakan sumber informasi yang dipercaya.

Dalam dunia pendidikan, yang hari ini semakin bertambah tuntutan untuk mengembangkan pembelajaran yang bermutu, media massa juga semakin menjadi perhatian para guru untuk dijadikan sumber belajar. Media massa dapat menjadi alat bagi guru untuk mengembangkan keterampilan berpikir kritis (Tanriverdi, 2008).

Maria Palazon (2000) mengatakan bahwa media adalah sumber dan sumber belajar bagi pengembangan berfikir kritis, baik tentang media itu sendiri maupun realita yang direpresentasikan melalui media. Hubungan media dengan belajar transformatif adalah dari cara-cara memahami isi media melalui proses decoding terhadap pesan-pesan teks, yang mendorong refleksi kritis serta pembelajaran aktif bagi siswa atau pembaca (Palazon, 2000).

Selain itu, media massa juga menjadi sarana belajar pendidikan moral bagi siswa tentang baik dan buruk, demikian menurut Rev James DiGiacomo (2000). Peneliti ini menegaskan lebih jauh bahwa cara siswa berfikir dan merasa tentang nilai baik dan buruk tergantung kepada seberapa besar budaya dominan masyarakat yang terwakili oleh isi media massa. Media massa ini dapat mempertegas atau melonggarkan nilai yang sudah diajarkan di rumah, di tempat ibadah, atau di sekolah (DiGiacomo, 2000).

Sejalan dengan itu, Belgin Tanriverdi \& Ozlem Apak (2008) menegaskan bahwa sumber belajar dari media mempengaruhi secara signifikan terhadap sikap dan tindakan siswa, baik terhadap dirinya, orang lain, maupun masyarakat. Penulis ini menyarankan lebih jauh agar disain dan adaptasi dari media tulisan harus merefleksikan multi-perspektif dan menghindari prasangka (Tanriverdi \& Apak, 2008).

Satu penelitian lain di California, Amerika Serikat, oleh lembaga pencegahan alkohol perguruan tinggi, atau HECfADAVP (Higher Education Center for Alcohol, Drug Abused, and Violence Prevence), pada tahun 2012, melalui proyek pencegahan penggunaan alkohol di kalangan mahasiswa dan komuintas kampus, terbukti bahwa kesuksesan proyek ini menekan pengguna alkohol dan juga meningkatkan pemahaman bahaya alkohol, didukung oleh kampanye 
yang dilakukan oleh media massa (HECfADAVP, 2012).

Media massa, di satu sisi, merupakan sumber belajar yang banyak manfaatnya; namun, di sisi lain, kemampuan siswa untuk menyerap informasi dari media massa perlu dipersiapkan dengan baik. Menurut Lynda Begsma (2011), kemampuan anak remaja dalam menyerap informasi dari media massa tergantung pada kesiapan mental siswa untuk mencerna informasi dari media tersebut.

Dalam hal ini perlu ada keseimbangan antara kecepatan daya tangkap anak terhadap simbol-simbol pesan dari media massa, dengan kemampuan nalarnya untuk mencerna informasi (Begsma, 2011). Sehubungan dengan itu, perlu upaya khusus bagi guru untuk membantu siswa dalam menggunakan media massa sebagai sarana belajar.

Pembelajaran saintifik yang dikembangkan di sekolah hari ini, melalui Kurikulum 2013, menggunakan langkah-langkah yang sistematis. Menurut Permendikbud RI (Peraturan Menteri Pendidikan dan Kebudayaan Republik Indonesia) Nomor 16 tentang Standar Proses, prinsip pembelajaran dalam Kurikulum 2013 adalah, antara lain: peserta didik mencari tahu, berbasis aneka sumber, proses sebagai penguatan penggunaan pendekatan ilmiah, dan jawaban dalam pembelajaran bersifat multi-perspektif. Pendekatan pembelajarn yang disarankan adalah pembelajaran berbasis penelitian atau pembelajaran berbasis projek (Kemendikbud RI, 2013). Secara sederhana, penerapan pendekatan saintifik dapat dikatakan sejalan dengan kerangka atau struktur ilmu yang dimulai dari fakta konsep, generalisasi, prinsip, dan teori.

\section{HASIL PENELITIAN DAN PEMBAHASAN}

Singgalang adalah nama sebuah suratkabar harian lokal, yang terbit di Kota Padang, Sumetara Barat, Indonesia. Suratkabar ini berdiri sejak tanggal 18 Desember 1968, tepatnya di Kota Padang. Suratkabar ini merupakan harian umum independen dengan misi: "Membina Harga Diri untuk Kesejahteran Nusa dan Bangsa”. Suratkabar Singgalang, selain menjalankan fungsi pers sebagai social control (pengawasan masyarakat), juga sebagai social participation (partisipasi masyarakat) dan social responsibility (tanggungjawab masyarakat) dalam proses pembangunan (Djabar, 2009).

Kontor Redaksi Suratkabar Singgalang berlokasi di Jalan Vetera No.17 Padang, Sumatera Barat. Suratkabar ini memiliki karakteristik "minang”, sekaligus menjadi daya tarik yang diracik dengan bahasa dan rubrik-rubrik Minang yang menghibur (Djabar, 2009:89).

Nilai Sosial dan Spiritual di Balik Berita dan Tajuk Koran Singgalang. Nilai sosial yang dikembangkan dalam penelusuran ini meliputi semua nilai yang terjadi dalam interaksi sosial, dan merupakan nilai yang dijadikan perekat hubungan sosial. Nilai yang masuk kategori ini seperti: toleransi, empati, saling menghormati, respon, memberi perhatian, dan seterusnya. Sedangkan nilai-nilai spiritual adalah nilai-nilai yang menyangkut kepada sikap batin, yakni nilai yang karena keberadaannya menimbulkan ketenangan hati nurani; dan yang diutamakan di sini adalah nilai yang bersumber dari nilai agama, seperti kejujuran, keadilan, kebersamaan, dan rasa syukur.

Jumlah berita dan tajuk yang dianalisis dalam penelitian ini adalah 28 berita dan 26 tajuk. Tanggal pengambilan secara acak dalam rentangan waktu, dari April 2015 sampai dengan Agustus 2015. Analisis dilakukan dua tahap: pertama, analisis teks; dan kedua, analisis konteks. Dari analisis teks ditemukan dua fenomena, yaitu frekuensi kemunculaan item nilai dari teks berita dan tajuk, serta nilai teringgi atau yang paling banyak teridentifikasi. Tabel 1 adalah berita yang dianalisis untuk menemukan nilai sosial dan spiritual.

Analisis Nilai dari Teks. Nilai spritual, yang teridentifikasi pada berita utama 
Tabel 1:

Daftar Judul Berita dan Tajuk Suratkabar Singgalang sebagai Sampel

\begin{tabular}{|c|c|c|c|}
\hline No & Tanggal Terbit & Judul Berita & Judul Tajuk \\
\hline 1 & 27 Maret 2015 & Polisi Gerebek Pabrik Saus & Partai Politik Sudahlah \\
\hline 2 & 1 April 2015 & $\begin{array}{l}\text { MK: Shadiq dan Fauzi Berpeluang Jadi } \\
\text { Gubernur }\end{array}$ & Persaingan Calon Gubernur \\
\hline 3 & 2 April 2015 & PTUN Tunda SK Menkum HAM & Revolusi Sepakbola Indonesia \\
\hline 4 & 4 April 2015 & UKM Bisa Pinjam Rp. 500 Juta ke Bank & Tiada Jeda dalam Politik \\
\hline 5 & 5 April 2015 & Teganya Pemerintah kepada Rakyat & -- \\
\hline 6 & 6 April 2015 & Partai Golkar Sulit Ajukan Calon Pilkada & UMKM Sulit Raih Kredit \\
\hline 7 & 8 April 2015 & Isu Reshuffle Menguat & Listrik Bukan Soal Tarif \\
\hline 8 & 9 April 2015 & Sumbar Dapat 19 Ribu Rumah Murah & Reshuffle, Presiden Jangan Dibebani \\
\hline 9 & 10 April 2015 & Mahasiswa Sumbar Diselamatkan Alqaeda & Rumah Murah Jangan Ada KKN \\
\hline 10 & 11 April 2015 & Surya Dharma Ali Ditahan & Politik Memuluskan Uang \\
\hline 11 & 12 April 2015 & Masalah Tak Berakhir di Tiang Gantungan & -- \\
\hline 12 & 13 April 2015 & Nilai di Bawah 5.5 Tak Wajib Mengulang & UN: Pentingnya Kejujuran \\
\hline 13 & 14 April 2015 & Golkar Sumbar Memanas & Bentuk Kegamangan ataukah Ketakutan \\
\hline 14 & 15 April 2015 & Ruko Terbakar, Tiga Tewas & Kepala Daerah Jangan Abaikan Tugas \\
\hline 15 & 1 Juni 2015 & KPU Beri Waktu Hingga 3 Hari & Makna Hari Lahir Pancasila \\
\hline 16 & 4 Juni 2015 & 7 Intruksi Presiden Menjelang Puasa & Jangan Ada Lagi Konflik Aparat \\
\hline 17 & 5 Juni 2015 & Tambang Longsor, Empat Pekerja Tewas & Langkah Tanggung Pemerintah \\
\hline 18 & 6 Juni 2015 & Pemerintah Akan Impor Cabe dan Bawang & Dilema Tambang Ilegal \\
\hline 19 & 6 Juli 2015 & Bandara Soetta Terbakar & $\begin{array}{l}\text { Lebaran: Pengamanan Harus } \\
\text { Ditingkatkan }\end{array}$ \\
\hline 20 & 14 Juli 2015 & IP dan NA Sudah Diteken & Menunggu Bakal Calon Kepala Daerah \\
\hline 21 & 22 Juli 2015 & Kantor DPP Parpol Padat Merayap & Melanjutkan Kepedulian Sosial \\
\hline 22 & 23 Juli 2015 & 139 Perda Tidak Pancasilais & Detik-detik Pilkada \\
\hline 23 & 31 Juli 2015 & BPJS Tidak Haram & Krisis Listrik Lagi \\
\hline 24 & 3 Agustus 2015 & Citilink Tergelincir di BIM & Rupiah Terpuruk \\
\hline 25 & 4 Agustus 2015 & Pemerintah Kehilangan Akal & Sudahlah, Hentikan Saja MOS \\
\hline 26 & 5 Agustus 2015 & BPJS Usul Premi Naik & Awas Krisis Moneter \\
\hline 27 & 6 Agustus 2015 & $\begin{array}{l}\text { Dua Wanita Korban Kurir Narkoba } \\
\text { Internasional Ditangkap }\end{array}$ & Jangan Kampanye Hitam \\
\hline 28 & 7 Agustus 2015 & Bukittinggi Dipenuhi Sampah & Permudah Calon Perseorangan \\
\hline
\end{tabular}

dalam suratkabar Singgalang, mencakup: kebebasan, rasa syukur, rasa percaya, kedamaian, keadilan, kepercayaan, kebenaran, keberanian, tanggungjawab, dan kesabaran. Tabel 2 adalah penyeberan item nilai spritual pada berita dan tajuk dalam suratkabar Singgalang.

Dari segi nilai spiritual, pertama dilihat dari frekuensi kemunculan nilai dalam berita dan tajuk koran Singgalang. Pada periode April 2015, yang mana koran Singgalang diambil secara berurutan sebanyak 16 eksemplar, terlihat ada 20 item nilai spiritual (religious) yang muncul pada berita, dan 6 item pada tajuk. Setelah dicek, penyebaran itu tidak merata pada setiap berita, melainkan pada berita tertentu menumpuk dan muncul nilai secara bersamaan, serta pada berita tertentu tidak ada komponen nilai sama sekali.

Karakteristik berita yang disampaikan pada berita utama beragam, mulai dari berita kriminal, politik, dan sosial. Hal yang menarik, kemunculan nilai spiritual pada periode April 2015 ini lebih banyak pada berita politik. Komponen nilai ini teridentifikasi pada berita, yang lebih cenderung sebagai ungkapan yang keluar dari pernyataan subjek berita, dan terkait 
Tabel 2:

Sebaran Nilai Spritual pada Berita Utama dan Tajuk Suratkabar Singgalang

\begin{tabular}{lccccccc}
\hline \multirow{2}{*}{ Nilai Spiritual } & \multicolumn{7}{c}{ Periode Terbit } \\
\cline { 2 - 7 } & $\begin{array}{c}\text { April 2015 } \\
\text { (14 Eksemplar) }\end{array}$ & $\begin{array}{c}\text { Juni 2015 } \\
\text { (4 Eksemplar) }\end{array}$ & $\begin{array}{c}\text { Juli dan Agustus 2015 } \\
\text { (10 Eksemplar) }\end{array}$ & $\begin{array}{c}\text { Jumlah Item } \\
\text { Nilai Spiritual }\end{array}$ \\
\cline { 2 - 8 } & Berita & Tajuk & Berita & Tajuk & Berita & Tajuk & 5 \\
\hline Kebebasan & 2 & - & - & - & 1 & 2 & 5 \\
Rasa syukur & 1 & - & 2 & 2 & - & - & 7 \\
Rasa percaya & 3 & 1 & - & - & 3 & - & 2 \\
Kedamaian & 1 & - & - & - & 1 & - & 8 \\
Keadilan & 3 & 1 & - & - & 3 & - & 6 \\
Kejujuran & 1 & 2 & - & 1 & - & 1 & 16 \\
Tanggungjawab & 6 & 2 & 2 & 4 & 2 & - & 3 \\
Kesabaran & 3 & - & - & - & 2 & -1 & 4 \\
Kebajikan & - & - & - & - & - & $\mathbf{8}$ & 5 \\
\hline Total Item Nilai & $\mathbf{2 0}$ & $\mathbf{6}$ & $\mathbf{5}$ & $\mathbf{7}$ & $\mathbf{1 2}$ & $\mathbf{8}$ \\
\hline
\end{tabular}

dengan konteks persoalan yang dialami subjek, seperti pertikaiaan antar partai, penahanan tokoh politik oleh KPK (Komisi Pemberantasan Korupsi), karena dugaan kasus politik dan kemasyarakatan.

Kencenderungan yang sama juga tampak pada berita di bulan Juni 2015 (sebanyak 4 eksemplar) dan bulan Juli 2015 hingga Agustus 2015. Artinya, dalam pemberitaan politik, seperti Pilkada (Pemilihan Langsung Kepala Daerah) dan Premi BPJS (Badan Penyelenggara Jaminan Sosial), lebih banyak muncul nilai-nilai spiritual yang kebanyakan sebagai ungkapan yang keluar dari subjek (tokoh politik, pemerintah).

Selanjutnya, dalam tajuk tidak terlalu banyak teridentifikasi nilai spiritual, tetapi kebanyakan nilai yang muncul adalah nilai sosial. Tajuk, sebagaimana umumnya, merupakan tema umum yang diangkat pada hari itu oleh sebuah koran, dan merupakan suara dari redaksi (Suwirta, 2015).

Kebanyakan tajuk dalam suratkabar Singgalang berupa ungkapan kekurangan dan masalah yang terjadi dalam masyarakat, baik oleh lembaga atau personil dari lembaga, seperti pemerintah, partai politik, dan pemegang kebijakan lainnya. Dalam hal ini, kebanyakan tajuk menyoroti kekuarangankekurangan dalam kinerja subjek, yang dibicrakan dalam tajuk.
Oleh karena itu, aspek nilai yang dapat diidentifikas dari komponen tajuk adalah nilai-nilai yang diekspresikan dalam bentuk kekurangan subjek dalam melakasanakannya. Sebagai contoh, tajuk tentang pertikaian partai, yang diungkapkannya adalah bahwa partai tidak lagi mempedulikan rakyat, tetapi lebih banyak memperjuangkan kepentingan partai, serta banyak hal yang diungkap tentang pelanggaran nilai oleh partai (Singgalang, 27/3/2015). Tajuk tampaknya lebih menyoroti persoalan sosial dan kemasyarakatan.

Dapat disimpulkan bahwa frekuensi nilai spiritual (religious), yang muncul dari berita atau tajuk suratkabar Singgalang, teridentifikasi tidak merata setiap hari. Selain itu, kemunculan nilai spritual lebih terkait dengan tema pemberitaan. Tema pemberitaan politik dan pemerintahan, misalnya, lebih banyak memunculkan nilai, terutama menyangkut subjek tertentu. Sedangkan untuk tajuk, kemunculan nilai spiritual lebih banyak dari segi "ketiadaan nilai” yang diinginkan pada diri subjek. Tepatnya, tajuk lebih mewakili kritik sosial terhadap subjek.

Selain frekuensi kemunculan nilai, hal kedua yang dapat disimpulkan dari temuan ini adalah: tiga kategori item nilai terbanyak yang muncul dalam berita atau tajuk adalah nilai tanggungjawab (16 item dari 58 total 
Tabel 3:

Sebaran Nilai Sosial pada Berita Utama dan Tajuk dalam Suratkabar Singgalang

\begin{tabular}{|c|c|c|c|c|c|c|c|}
\hline \multirow{3}{*}{ Nilai Sosial } & \multicolumn{6}{|c|}{ Periode Terbit } & \multirow{3}{*}{$\begin{array}{c}\text { Jumlah Item } \\
\text { Nilai Sosial }\end{array}$} \\
\hline & \multicolumn{2}{|c|}{$\begin{array}{c}\text { April } 2015 \\
\text { (14 Eksemplar) }\end{array}$} & \multicolumn{2}{|c|}{$\begin{array}{c}\text { Juni } 2015 \\
\text { (6 Eksemplar) }\end{array}$} & \multicolumn{2}{|c|}{$\begin{array}{c}\text { Juli } 2015 \text { dan Agustus } \\
2015 \text { (10 Eksemplar) }\end{array}$} & \\
\hline & Berita & Tajuk & Berita & Tajuk & Berita & Tajuk & \\
\hline Taat aturan/norma & 1 & 1 & 1 & - & 4 & 5 & 12 \\
\hline Cepat tanggap & 1 & - & - & - & - & - & 1 \\
\hline Kepedulian & 4 & - & - & 2 & 14 & 10 & 30 \\
\hline Menghormati orang lain & 4 & - & - & - & - & - & 4 \\
\hline Tanggungjawab sosial & 2 & 3 & 4 & 3 & 14 & 9 & 35 \\
\hline Kerjasama & 4 & - & 2 & - & 11 & 5 & 22 \\
\hline Toleransi & 4 & - & - & - & - & - & 4 \\
\hline Persamaan hak & 2 & 2 & - & - & 3 & 5 & 13 \\
\hline Persatuan & 1 & 1 & - & 3 & 4 & - & 9 \\
\hline Jumlah Item Nilai & 23 & 7 & 7 & 8 & 50 & 34 & 129 \\
\hline
\end{tabular}

item dari 28 eksemplar koran); di bawah itu adalah nilai keadilan (8 item); dan ketiga adalah nilai rasa percaya (7 item); serta selanjutnya adalah nilai kejujuran (6 item). Dibawah itu adalah nilai kebebasan dan nilai rasa syukur, masing-masing 5 item.

Selanjutnya, nilai-nilai sosial yang dominan tampak pada teks berita dan tajuk suratkabar Singgalam adalah: taat aturan, cepat tanggap, kepedulian, menghormati orang lain, tanggungjawab sosial, kerjasama, toleransi, persamaan hak, dan persatuan. Nilai-nilai sosial teridentifikasi pada semua jenis berita, seperti berita kriminal yang mengungkapkan kinerja polisi, berita politik pemilihan kepala daerah, dan pertikaian internal partai; namun dalam berita yang bernuansa sosial, lebih banyak muncul nilai sosial, seperti berita yang muncul di bulan Juli 2015 dan Agustus 2015, yang menyoroti masalah sampah kota (Singgalang, 7/8/2015) dan BPJS atau Badan Penyelenggara Jaminan Sosial (Singgalang, 31/7/2015; dan Singgalang, 5/8/2015;).

Nilai sosial tampak pada tindakan subjek yang diungkap dalam berita. Dari tabel 2 tampak bahwa nilai sosial muncul pada berita bulan April 2015, dari 16 eksemplar berita itu ada 23 nilai sosial; 7 item nilai di bulan Juni 2015 dari 6 eksemplar berita; serta di bulan Juli 2015 dan Agustus 2015, dari 10 eksemplar berita itu ada 50 item nilai sosial yang muncul. Kemungkinan fenomena ini terkait dengan topik berita yang diangkat pada periode berkenaan. Kebanyakan topik berita menyangkut masalah sosial dan kemasyarakatan, seperti kebakaran bandara Soeta (Soekarno-Hatta), BPJS, dan isu-isu di sekitar Pilkada (Pemilihan Langsung Kepada Daerah).

Dalam tajuk, tampaknya item nilai sosial yang teridentifikasi lebih sedikit. Sebagaimana dikemukakan di atas, kebanyakan tema tajuk adalah kritik sosial, sehingga ungkapan dalam teks berupa kekurangan dari subjek yang dibicarakan, atau paling tinggi adalah harapan terhadap subjek untuk mewujudkan nilai-nilai sosial yang baik dalam tindakannya.

Nilai yang paling banyak muncul adalah tanggung jawab sosial (35 item dari 129 item nilai sosial); di bawah itu adalah nilai kepedulian (30 item); dan diikuti oleh nilai kerjasama (22 item). Lebih rendah lagi adalah nilai persamaan hak (13 item dari 126 item nilai sosial); dan setelah itu adalah nilai taat aturan (12 item). Hal yang menarik dari item terbanyak itu adalah pada nilai spiritual "tanggungjawab", yang merupakan item nilai terbanyak, yang muncul pada teks. Pada aspek nilai sosial, juga "nilai tanggunngjawab sosial" 
merupakan item terbanyak. Gambaran ini dapat dilihat pada tabel 3.

Analisis Nilai dari Konteks. Setelah melihat tampilan nilai dari teks di atas, lebih jauh dilihat siapa yang menjadi subjek dan objek dari teks. Dari analisis yang telah dilakukan, nilai tanggungjawab dan tanggungjawab sosial selalu bersamaan munculnya. Oleh sebab itu, frekuensi keduanya juga sama menempati yang terbanyak.

Dilihat dari topik berita, nilai tanggungjawab dan tanggungjawab sosial muncul dalam berita sosial yang berjudul: "Pemerintah Akan Impor Cabe dan Bawang" (Singgalang, 6/6/2015); “7 Instruksi Presiden Menjelang Puasa” (Singgalang, 4/6/2015); "Ruko Terbakar, Tiga Tewas" (Singgalang, 15/4/2015); "Bandara Soeta Terbakar" (Singgalang, 6/7/2015); “BPJS Tidak Haram” (Singgalang, 31/7/2015); dan "Bukittinggi Dipenuhi Sampah” (Singgalang, 7/8/2015).

Pada berita politik, nilai tanggungjawab dan tanggungjawab sosial muncul, dengan judul: "IP dan NA Sudah Diteken" (Singgalang, 14/7/2015); “Kantor DPP Parpol Padat Merayap” (Singgalang, 22/7/2015); “139 Perda Tidak Pancasilais” (Singgalang, 23/7/2015); "Pemerintah Kehilangan Akal” (Singgalang, 4/8/2015); dan “BPJS Usul Premi Naik” (Singgalang, 5/8/2015).

Pada berita tersebut, nilai tanggungjawab dan tanggungjawab sosial disimpulkan dari ungkapan atau berita subjek, seperti pemerintah, pimpinan perusahaan, atau penanggungjawab urusan, yang menggambarkan upaya dan tindakan yang dilakukan untuk memberi penekanan atas tindakan yang telah dilakukan sebagai wujud tanggunjawab mereka. Hal yang dapat disimpulkan dari nilai ini adalah sifat pengungkap nilai yang vertikal, dari “pimpinan kepada bawahan”. Di sini, pembuat berita menjadi corong dari pihak "atas" untuk menyampaikan berbagai upaya atau tindakan yang sifatnya memberitahu "bawahan” tentang tindakan atau upaya yang sudah dilakukan dalam menunaikan kewajiban. Dapat disimpulkan bahwa nilai tanggungjawab dan tanggungjawab sosial yang dapat diidentifikasi dari berita tersebut adalah bersifat vertikal.

Sedangkan konteks nilai tanggungjawab dan tanggungjawab sosial dalam tajuk, juga bersifat vertikal, yakni dari "bawah" ke "atas". Dalam hal ini, tajuk sebagai kontrol sosial, sesuai dengan misi suratkabar Singgalang, mengungkapkan berbagai kekurangan "pihak atas” dan mengharapkan mereka untuk memperbaiki hal-hal yang menyangkut tugas dan tanggung jawab mereka.

Nilai sosial kedua terbanyak adalah “kepedulian”. Nilai ini dapat teridentifikasi pada berita dan tajuk, yang berjudul: "MK: Shadiq dan Fauzi Berpeluang Jadi Gubernur” (Singgalang, 1/4/2015); "UKM Bisa Pinjam Rp. 500 Juta ke Bank" (Singgalang, 4/4/2015); "Ruko Terbakar, Tiga Tewas” (Singgalang, 15/4/2015); “Bandara Soeta Terbakar” (Singgalang, 6/7/2015); "Revolusi Sepakbola Indonesia" (Singgalang, 2/4/2015); “UMKM Sulit Raih Kredit” (Singgalang, 6/4/2015); "Lebaran: Pengamanan Harus Ditingkatkan" (Singgalang, 6/7/2015); "Menunggu Bakal Calon Kepala Daerah” (Singgalang, 14/7/2015); dan "Melanjutkan Kepedulian Sosial” (Singgalang, 22/7/2015).

Sedikit berbeda dengan konteks nilai tanggungjawab sosial, nilai kepedulian tampak dari prilaku langsung subjek dalam menangani masalah yang terjadi. Hal ini terutama tampak pada berita dan tajuk yang bertemakan sosial. Tetapi, pada berita yang bersifat politik, nilai kepedulian hanya berupa pernyataan atau pengakuan terhadap adanya hak atau keberadan pihak lain. Dilihat dari pengungkapan nilai kepedulian, ianya lebih bersifat horizontal.

Untuk nilai spiritual, nilai tertinggi kedua adalah nilai “keadilan”. Ini tampak pada berita yang berhubungan dengan nilai keadilan, seperti: “Surya Dharma 
Ali Ditahan” (Singgalang, 11/4/2015);

"Pemerintah Akan Impor Cabe dan Bawang" (Singgalang, 6/6/2015); "139 Perda Tidak Pancasilais” (Singgalang, 23/7/2015); dan "BPJS Usul Premi Naik” (Singgalang, 5/8/2015). Sedangkan pada tajuk yang berhubungan dengan nilai keadilan adalah: "Persaingan Calon Gubernur" (Singgalang, 1/4/2015); "Bentuk Kegamangan ataukah Ketakutan” (Singgalang, 14/4/2015); “Jangan Kampanye Hitam” (Singgalang, 6/8/2015); “Awas Krisi Moneter” (Singgalang, 5/8/2015); dan "Sudahlah, Hentikan Saja MOS” (Singgalang, 4/8/2015).

Penampakan nilai "keadilan” pada berita dan tajuk dalam suratkabar Singgalang memiliki makna yang beragam bila dilihat dari subjek. Pada berita "Surya Dharma Ali Ditahan” (Singgalang, 11/4/2015), nilai keadilan terungkap dari alasan penahanan. Sedangkan pada berita lain, nilai keadilan disimpulkan dari alasan pengambilan satu keputusan, yang ditujukan untuk kesamaan hak dan kesempatan. Dilihat dari sifat nilai, maka pengungkapan nilai "keadilan” dalam teks berita atau tajuk lebih bersifat vertikal, yang merupakan dasar bagi suatu tindakan, atau sebagai penjelas mengapa tindakan tertentu diambil.

Dari penjelasan di atas, baik makna nilai dari teks maupun konteks, dapat disimpulkan bahwa berita dan tajuk dalam suratkabar sesungguhnya memiliki pesan-pesan nilai yang tidak disadari oleh pembaca. Nilai-nilai itu menyatu didalam teks yang tidak dapat dibaca beigitu saja bersamaan dengan teks, tetapi membutuhkan analisis dan pemahaman kritis terhadap teks. Dalam proses membaca, secara tidak langsung, orang yang membaca teks akan dibawa kedalam pemahaman untuk menerima atau menolak "kondisi” subjek yang diberitakan. Di sini, peran nilai masuk kedalam pikiran pembaca teks.

Dari analisis teks di atas, nilai-nilai spiritual dan sosial yang terbanyak adalah “tanggungjawab” dan "tanggungjawab sosial”. Kedua terbanyak untuk nilai spirtitual adalah "keadilan”; dan untuk nilai sosial adalah "kepedulian”. Dilihat dari konteks, hanya nilai “kepedulian” yang bersifat horizontal, yakni mengungkap kepedulian sesama anggota masyarakat; sedangkan nilai lainnya yang bersifat vertikal hanya berupa ungkapan atau alasan yang disampaikan dari pihak pemerintah atau pimpinan dalam mengambil suatu tindakan.

\section{Implikasi bagi Proses Pembelajaran dan}

Pengajaran. Sebagaimana diketahui, selama ini guru sudah terbiasa menugaskan siswa untuk membaca sumber belajar, selain dari buku, yakni dari koran dan media massa. Proses penugasan ini sebatas mengumpulkan informasi dan memperkaya ranah kognitif siswa. Belum ada upaya dari guru untuk memngarahkan siswa memperlajari aspek nilai dari teks. Setelah terbukti dari penelitian ini bahwa begitu banyaknnya aspek nilai yang dapat digali dari satu pemeberitaan, maka perlu pula guru memperhatikan aspek tertentu dalam menugaskan siswa dalam mengeksplorasi bahan ajar. Aspek-aspek tersebut adalah sebagai berikut:

Pertama, pemilihan media yang tepat. Untuk ini, guru perlu terlebih dahulu menyeleksi apakah yang akan diambil itu jenis berita, tajuk, atau opini. Kemudian, guru juga harus tahu latar belakang dari sebuah media, apakah berlatang belakang relijius, nasionalis, atau kedaerhaan. Beradasarkan ini, guru menetapkan nilai-nilai apa yang mungkin dapat diidentifikasi dari media massa tersebut.

Kedua, perlu ada panduan membaca bagi siswa dan mungkin siswa diarahkan untuk mencari ide pokok, yang selanjutnya ke konsep dan nilai. Mencakup juga dalam panduan itu cara-cara menyimpulkan nilai dari konsep. Panduan itu lebih baik berupa tabel yang siap diisi oleh siswa.

Ketiga, guru perlu menguasai keterampilan membaca dengan kritis, sehingga ketika siswa mengeksplorasi bacaan sesuai dengan panduan, guru sudah menyiapkan bantuan berupa kiat-kiat dalam membaca. 
Keempat, tahap-tahap yang harus dilalui dalam membaca sebuah teks media massa perlu dipertegas dalam kegiatan inti pembelajaran, seperti: penetapan topik, analisisi isi teks, dan analisis konteks atau interpretasi teks. Artinya, membaca sumber bukan sekedar pengayaan bahan bacaan siswa, tetapi menyatu dalam proses pembelajaran, atau sekaligus proses pemebajaran dan pengajaran itu sendiri.

\section{KESIMPULAN}

Pendekatan saintifik dalam pembelajaran, dengan menerapkan tahap mengamati, menanya, mengumpulkan informasi, mengasosiasi, menyajikan, dan mengkomunikasikan, merupakan acuan dasar dalam pengembangan kegiatan belajar menurut Kurikulum 2013. Bertolak dari acuan ini, guru memiliki keleluasaan gerak dalam mengeksplorasi berfikir siswa, karena menginggat fungsi guru sebagai “pengembang kurikulum”. Setiap fase dalam pendekatan saintifik merupakan bagian yang sangat menarik untuk dikembangkan. Pada fase-fase tersebut, guru dapat merancang berbagai strategi dan sumber belajar yang sesuai dengan target pembelajaran.

Kongkritnya, upaya ini bisa dilakukan dengan contoh dalam memadukan langkahlangkah saintifik dengan analisis media massa. Pada tahap mengamati, misalnya, siswa pada dasarnya adalah melihat fenomena yang ada, tanpa menilai atau mengelompokan. Tahap ini bisa dimulai dengan membaca secara umum bahan bacaan. Siswa hanya dipandu dengan panduan observasi tentang aspek yang akan diamati, sesuai dengan target pembelajaran. Target dari tahap pengamatan adalah mengumpulkan informasi.

Tahap kedua, yakni menanya, merupakan tindak-lanjut untuk menggali kemampuan kritis siswa. Melalui temuan dari bacaan, siswa dipandu lagi untuk mengelompokan informasi, mana yang bersifat pengetahuan dan mana yang sarat dengan nilai. Siswa diarahkan untuk mempertanyakan "mengapa” demikian; "hal-hal apa yang melatarbelakanginya”; dan tahap ini merupakan upaya awal membangun konsep.

Tahap mengumpulkan informasi dan mengasosiasi adalah tahap mengkondisikan siswa dalam melakukan pengumpulan data tambahan dan pengujian jawaban pada tahap menanya dan mengembangkan analisis, dengan memperkuat jawaban dari tahap sebelumnya. Di sini, siswa dipandu untuk menjawab pertanyaan yang menyangkut pengetahuan dan nilai, yang diangkat pada tahap menanya. Peran sumber bacaan, seperti media massa, kembali diperlukan sebagai landasan untuk mengambil kesimpulan yang lebih rasional.

Tahap berikutnya adalah menyajikan kesimpulan atau generalisasi, yang telah digali dari tahap-tahap sebelumnya. Guru memberi panduan tentang garis-garis besar generalisasi dan nilai yang dapat disimpulkan oleh siswa. Tahap ini merupakan tahap penting sebagai puncak dari langkah saintifik. Oleh sebab itu, guru perlu memberi panduan tentang bagaimana cara siswa menggali informasi dari sumber bacaan secara analitis dan kritis. Jika tahap ini berhasil, maka berarti proses pembelajaran telah menjadi sarana untuk melatih daya kritis siswa.

Tahap akhir hanyalah sebuah publikasi terbatas, yakni mengkomunikasikan temuan tersebut. Pembelajaran menganalisis media massa sebenarnya adalah pembelajaran yang harus implisit dan berproses bersama langkah saintifik. Artinya, pembelajaran PPKn (Pendidikan Pancasila dan Kewarganegaraan), dengan menggunakan media massa, adalah pembelajaran yang bermakna secara ilmiah, sekaligus merupakan pembelajaran untuk melek media. ${ }^{1}$

${ }^{1}$ Pernyataan: Dengan ini, kami menyatakan bahwa artikel ini adalah karya asli kami berdua, ianya bukan hasil jiplakan, karena sumber-sumber rujukan yang kami kutip dinyatakan secara jelas dalam daftar Referensi. Artikel ini juga belum pernah direviu dan belum pernah diterbitkan oleh jurnal ilmiah lain. 


\section{Referensi}

Begsma, Lynda. (2011). “Media Literacy and Health Promotion for Adolescent” dalam Journal of Media Literacy Education, Vol.31, No.11, hlm.2528. Tersedia secara online juga di: www.jmle.org [diakses di Padang, Indonesia: 20 Januari 2016].

Berita-berita terpilih dalam suratkabar Singgalang. Padang, Sumatera Barat: Maret 2015 hingga Agustus 2015.

Desy N., Wahyu. (2011). "Media Massa dan Pendidikan Karakter”. Tersedia secara online juga di: http://makassar.tribunnews.com/2011/09/26/ media-massa-dan-pendidikan-karakter [diakses di Padang, Indonesia: 20 Januari 2016].

DiGiacomo, Rev James. (2000). “Teaching Right from Wrong: The Moral Education of Today's Youth” dalam ERIC Document, ED454124.

Djabar, H. Basril. (2009). Otobiografi H. Basril Djabar. Padang: t.p. [tanpa penerbit].

HECfADAVP [Higher Education Center for Alcohol, Drug Abused, and Violence Prevence]. (2012). “The Role of Media in Prevention” dalam ERIC Document, ED532224.

Kemendikbud RI [Kementerian Pendidikan dan Kebudayaan Republik Indonesia]. (2013). Peraturan Menteri Pendidikan dan Kebudayaan Republik Indonesia, Nomor 16 tentang Standar
Proses. Jakarta: Setjen [Sekretariat Jenderal] Kemendikbud RI.

Krippendorf, G. (1980). Content Analysis: An Introduction to its Methodology. Southen Oak: SAGE Publication.

Palazon, Maria. (2000). “The Media and Transformative Learning” dalam ERIC Document, ED443971.

Prasad, B. Devi. (2008). “Content Analysis: A Method in Social Science Research” dalam D.K. Laldas \& V. Bhaskaran [eds]. Research Methods for Social Work. New Delhi: Rhawat, hlm.173-193.

Suwirta, Andi. (2015). Revolusi Indonesia dalam News \& Views: Sebuah Antologi Sejarah. Yogyakarta: Penerbit Ombak.

Tajuk-tajuk terpilih dalam suratkabar Singgalang. Padang, Sumatera Barat: Maret 2015 hingga Agustus 2015.

Tanriverdi, Belgin. (2008). "Media Literacy Education in the Balkan Countries: Greek and Turkey Case" dalam ERIC Document, ED504855.

Tanriverdi, Belgin \& Ozlem Apak. (2008). "Culture and Language Teaching Through Media” dalam ERIC Document, ED504866.

Wan, Guafon \& Diane Gut. (2008). "Roles of Media and Media Education: Lives of Chinese and American Adolescent" dalam New Horizon in Education, Vol.6, No.2 [October], hlm.28-42. 
ISNARMI MOEIS \& JUNAIDI INDRAWADI,

Analisis Isi Pesan Nilai dalam Suratkabar Singgalang

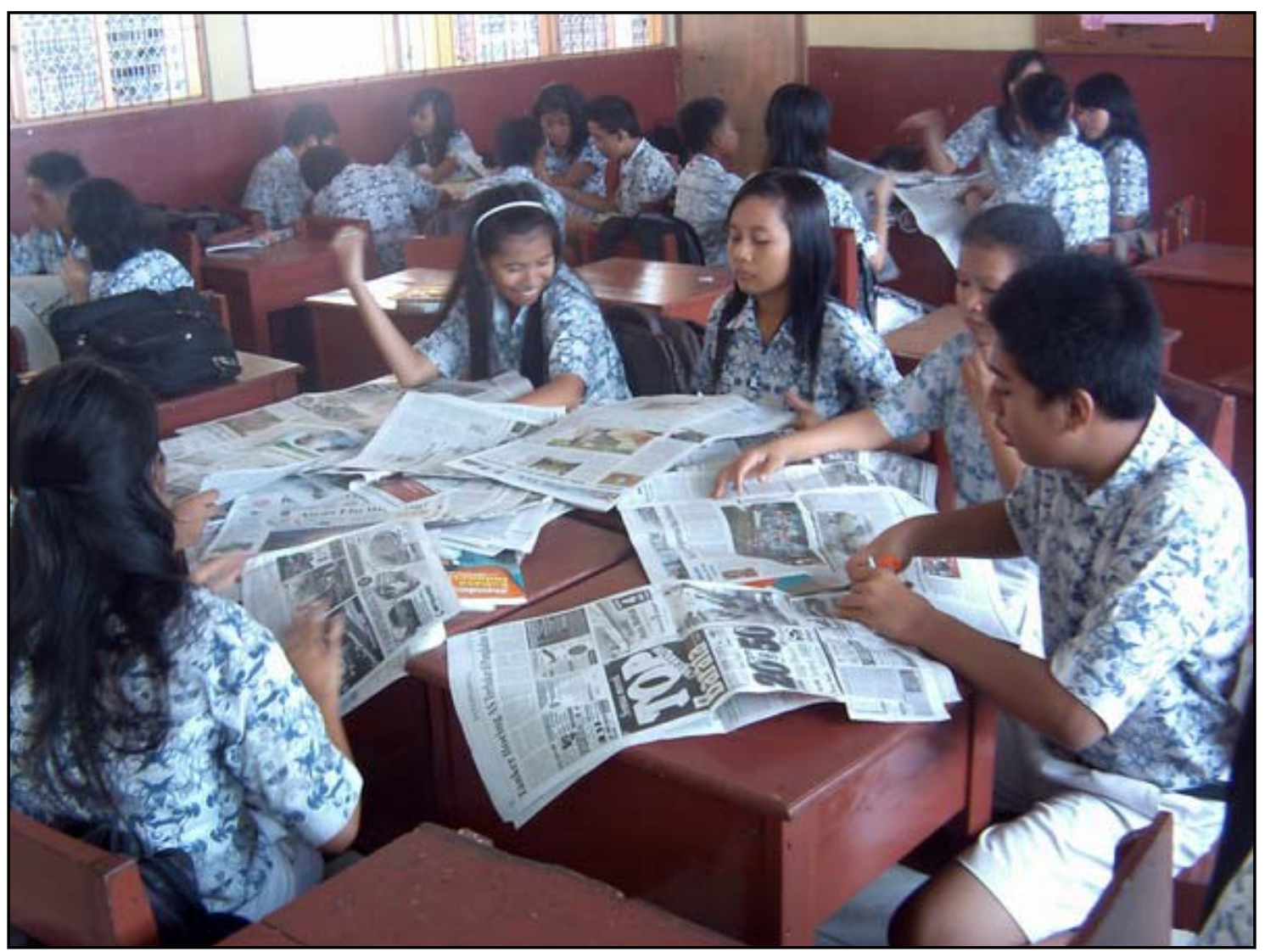

Murid Sekolah dan Pemanfaatan Media Massa di Indonesia

(Sumber: http://butheyulian.blog.com/, 20/1/2016)

Pembelajaran menganalisis media massa sebenarnya adalah pembelajaran yang harus implisit dan berproses bersama langkah saintifik. Artinya, pembelajaran PPKn (Pendidikan Pancasila dan Kewarganegaraan), dengan menggunakan media massa, adalah pembelajaran yang bermakna secara ilmiah, sekaligus merupakan pembelajaran untuk melek media. 